Kenyeres, János. "Manifestations of Hungarian Identity in Literature.” Hungarian Cultural Studies. e-Journal of the American Hungarian Educators Association, Volume 12 (2019) DOI: 10.5195/ahea.2019.347

\title{
Manifestations of Hungarian Identity in Literature
}

\section{János Kenyeres}

\begin{abstract}
Concentrating on some important literary and theoretical works, this article examines how Hungarian identity has been given different meanings and various forms of expression over the past few centuries. Hungarian identity is an ever-changing concept and the question of belonging and what is Hungarian has been subject to numerous interpretations. Linked to periods of victory and prosperity, and their opposite, defeat, humiliation and poverty, as well as revolt, revolution, defiance, resignation and even silence, the alternating forms of national identity can all be found in literature. The fact that Hungarians have more than one text (the "Hymn," the "Appeal" and, recently, the "Székely Hymn") that assumes the status or quasi-status of a national anthem itself indicates the multiplicity of Hungarian identity. These texts have become part and parcel of national identity due to the frequency with which individuals encounter them from their early childhood on. This is coupled with a strong Hungarian literary canon, which also plays an essential role in identity building. In the absence of a solid literary canon, literary works are less significant in the identity structure of many other nations; in larger countries a diversity of texts are taught at school due to substantial regional differences. In contrast, the Hungarian school system has traditionally placed and still places emphasis on a stable and only slowly changing literary canon which, in turn, leads to a body of literature known to most members of society.
\end{abstract}

\section{Keywords: Hungarian identity, national identity, Hungarian literature, nation-building}

Biography: János Kenyeres is the Director and Associate Professor of the School of English and American Studies at Eötvös Loránd University. He graduated from Eötvös Loránd University in English and Hungarian literature in 1991 and earned his doctoral degree in literary studies from the Hungarian Academy of Sciences in 2000. He was Visiting Professor of Hungarian at the University of Toronto in 2018-2019, 2015 and 2005-2008, where his work focused on Hungarian literature, cinema and culture. He became a habilitated doctor in literary studies in 2014 and is a member of the Doctoral School of Literary Studies at Eötvös Loránd University. He has been co-editor of The AnaChronisT since 2002._kenyeres.janos@btk.elte.hu

In 1939, the year the Second World War broke out, a group of prominent Hungarian intellectuals published a book with the title Mi a magyar? ['What is the Hungarian?'] to answer the eponymous question. Among others, the contributors to this volume included such authors as Mihály Babits, Zoltán Kodály, Sándor Eckhardt, Béla Zolnai and Gyula Szekfü, intellectuals who represented different disciplines and ideological positions. Although they could not 
Kenyeres, János. "Manifestations of Hungarian Identity in Literature.” Hungarian Cultural Studies. e-Journal of the American Hungarian Educators Association, Volume 12 (2019) DOI: 10.5195/ahea.2019.347

conclusively answer the difficult question posed in the title and some of their ideas sound outdated or even obscure today, the authors approached the issue from various perspectives, including history, linguistics, stylistics, race, ethnography, music, literature and other arts. In 1939, as Germany's influence grew and the danger of violence was becoming imminent in Europe, the authors' main objective was to define the character of the Hungarian nation, thereby distinguishing it from other nations and pinpointing its unique features. Their immediate goal, however, was to break away from the ideas expressed in Lajos Prohászka' Vándor és bujdosó ['The Wanderer and the Outlaw'] (1936), a work whose author proclaimed that in place of the declining Western European cultures, the Germans and Italians would create a cultural dynamism that the Hungarians (the outlaws, metaphorically speaking) could join as well. Although Prohászka was far from being an advocate of Nazi ideology - in fact his ideal was humanism and refused biological or racial concepts as a proponent of Geistgeschichte or intellectual history (Trencsényi et al 2018: 179-180) —in 1939 the aforementioned group of Hungarian intellectuals believed that his German orientation had become threatening and the integrity of the nation had to be defended against German influence. This was the immediate reason for their own publication; most articles in the volume expressly refuted what they thought of as Prohászka's German model.

Literature had an important role in the volume Mi a magyar? as an essential element of Hungarian identity; in the present analysis I will map out some ways in which literature has been linked to national identity since the nineteenth century. To be more precise, I am primarily interested in the ways in which Hungarian literature expresses national belonging and how it contributes to national identity. The objective of the authors of the volume Mi a magyar? was something else; they were preoccupied with national characterology, the characteristic features of the Hungarians. In this respect, their search bore no fruit and although they managed to disperse a number of misunderstandings and hazy concepts, the value of which cannot be overrated, what they demonstrated in the final analysis was that no single, peculiar features are exclusively Hungarian. The important conclusion which may be drawn from the volume is that "what is the Hungarian" is a special combination of individual features that are otherwise shared by other nations as well. It is the combination, the mix of all the elements culminating in Hungarian tradition and Hungarian experience, rather than the individual components, which is unique. My own objective in this study is different; it is to show some characteristic ways in which belonging to Hungary as a community while engaging in the problems and questions that the nation has faced during the past roughly two hundred years has manifested itself in Hungarian literature.

National identity is an ever-changing concept and the ways in which it was understood in the past is primarily relevant in the context of how it is understood today. Like culture, identity is a living thing that is addressed, questioned and interpreted today. Like tradition, Hungarian identity is not a sacred obligation to be maintained and adhered to; nor is it a historical relic, but 
Kenyeres, János. "Manifestations of Hungarian Identity in Literature.” Hungarian Cultural Studies. e-Journal of the American Hungarian Educators Association, Volume 12 (2019) DOI: 10.5195/ahea.2019.347

rather something that lives in us, something that is an integral part of us, something that we cannot do away with. It is an internal bond, not an external compulsion.

In his essay entitled "A magyar jellemröl” ['On the Hungarian Character'] in the aforementioned volume, Mihály Babits makes a few noteworthy statements. For example, he claims that explicit "statements of great Hungarians about the Hungarians" ["nagy magyarok nyilatkozatai a magyarságról' (Babits 2018:87); (Babits 1939: 42] are less significant and substantial than the more secretive, less showy suggestions in their works. ${ }^{1}$ He maintains that "Poetry that springs from the unconscious always speaks the truth about the soul" ["A tudattalanból föltörö költészet a lélekröl mindig igazat mond'] (Babits 2018, 87; Babits 1939: 42) and deliberate, conscious declarations are therefore less revelatory. As he claims, "A love poem may be a more reliable source on Hungarian character than the finest proclamations of the poet about Hungarianness" ['Egy szerelmes vers megbízhatóbb forrás lehet a magyar karakterre nézve, mint a költő legszebb kijelentései a magyarságról'] (Babits 2018: 87; Babits 1939: 42). It is the way of thinking, the mentality, the formulation of ideas and emotions underlying conscious statements that should be considered when examining Hungarian features. How this works is a difficult question to answer and Babits does not investigate it further; he is, however, right in observing that it is not the explicit declamations, the high-sounding, puffed-up and sonorous declarations about Hungarianness that give us the best clues about the nature of national identity.

Love poems or any other literary works for that matter may indeed reveal more about national identity than explicit declamations; as building blocks of national identity they need to be part of the literary canon, a body of literature that people know and remember. In other words, it is important for works of literature to be in the collective cultural memory of the community called the nation in order to enable them to play a role in national identity.

In nineteenth-century Hungarian literature, the expression of belonging often manifests itself in the description of the landscape or the articulation of a sense of concern about the present and the future of the country. This latter element is in turn often contrasted with the past, hence the evocation of history in literature. The alternating forms of national identity presenting themselves in the various historical periods (including those of great victories and prosperity) are almost always portrayed as having occurred in the remote past while their opposites - defeat, humiliation and poverty, as well as revolt, revolution, defiance, resignation and even silenceare usually shown as being concurrent with the present or the recent past.

All of these phenomena can be found in literature and are often depicted through the portrayal of individuals. Some works merely describe the magnificence and beauty of the Hungarian landscape and the speaker's admiration. These poems are pure expressions of a sense of belonging to Hungary as a geographical place, a homeland. Other poems articulate the

\footnotetext{
${ }^{1}$ All translations of excerpts cited in this article from "A Magyar jellemröl” ['On Hungarian Character'] are by Richard Robinson and published in Babits: 2018.
} 
Kenyeres, János. "Manifestations of Hungarian Identity in Literature.” Hungarian Cultural Studies. e-Journal of the American Hungarian Educators Association, Volume 12 (2019) DOI: 10.5195/ahea.2019.347

speaker's attachment to a group of people. Other works combine this type of descriptions with concern over the fate of individuals, thereby formulating a critical voice about the current situation and the present and future of the larger community.

When surveying Hungarian literature from the nineteenth century to the present, it can be observed that the issues discussed throughout various historical periods were almost always reflected in literature. However, Hungarian literature sees its role as more than merely a reflection. Starting from the early nineteenth century, the writer or poet assumed the special role of the vates, the prophet or seer who was responsible for leading the nation through its sea of troubles. At times, we still believe even today that writers have a unique role in shaping the fate of the nation. This assumed role largely vanished by the 1930s and is generally unknown to nations in Western Europe or North America. As Gyula Illyés remarked in 1963 in the preface of the French edition of László Németh's novel, Iszony ['Revulsion'] (1947), readers in the West are often puzzled to see how, in Hungarian literature, the writer, poet or dramatist always calls attention to the threat that there is a flood on the Danube and demands that the dams should be fortified. Where is the water authority, where is the government, they ask in happier countries (see Z. Kenyeres 2004: 98)? The answer is as simple as this: some institutions were not functioning well in Hungary and Eastern Europe. Only the authors of literature could truthfully address sensitive issues since formal journalism was being censored. With its figures of speech and hidden messages tucked "between the lines," poetic language is able to fulfil this task. This feature of Hungarian literature is closely linked to a strong critical attitude toward the prevailing social, historical or political circumstances that emerges as a constant call for a change. Even though the writer is no longer considered a prophet today, this critical attitude has been retained in Hungarian literature until the present time.

The first half of the nineteenth century was an era of nation-building during which economic development, the advancement of scholarship, the growth of the arts and the status of the Hungarian language were high on the agenda. Literature therefore played an important role in promoting national self-awareness. Ferenc Kölcsey's "Himnusz" ['Hymn'], the national anthem, is a key work in this respect; it is part and parcel of the Hungarian literary canon and an essential constituent of Hungarian identity. As is known, the poem was completed on January 22, 1823, and its subtitle reads: "A magyar nép zivataros századaiból" ['From the stormy centuries of the Hungarian nation']. The story of the subtitle is relevant from the point of view of censorship (or our own conceptions about censorship); although it is part of the original manuscript, the poem was first published in Károly Kisfaludi's Aurora in 1828 without the subtitle. The poem next appeared in a collection of Kölcsey's works in 1832 with the subtitle. With its reference to the past rather than the present, the subtitle is often thought to have been added by Kölcsey to serve as "the juicy piece of meat carried by the burglar to distract the watchdog of the mind" (McLuhan 1964: 18), who, in this case, refers to the mind of the censor. This theory concerning censorship, however, has been refuted, as the poem went largely unnoticed when it was first published and only attracted a limited amount of attention in 1832 (see Nyáry 2019). 
Kenyeres, János. "Manifestations of Hungarian Identity in Literature.” Hungarian Cultural Studies. e-Journal of the American Hungarian Educators Association, Volume 12 (2019) DOI: 10.5195/ahea.2019.347

The musical accompaniment of the poem we know today was rendered by the composer Ferenc Erkel in 1844 as a result of a competition advertised to set the poem to music. Erkel won the competition and since the end of the 1850 s it has become customary to sing the poem together with its music on national holidays and other celebratory events. Often regarded as sorrowful when compared to other national anthems, the musical version is frequently played without vocals. In 1938, Ernö Dohnányi made some modifications to the music of the "Hymn" and it is this version that we know today. In 2013, at the request of the Hungarian Olympic Committee, a ninety-second version of the "Hymn" was made that follows the tempo of Erkel's original conception more closely. This speedier version is much less sombre than the one most people are familiar with today and even contains the original chimes to commemorate the Siege of Nándorfehérvár ['Belgrade'] of 1456 (see Nyáry 2019).

Kölcsey's poem is a prayer to God in line with the Latin genre of hymnus, a song of praise that is usually addressed to a deity in the form of an adoration or prayer. The poem takes the readers through the vicissitudes of Hungarian history, with the main message being that the nation has greatly suffered for its sins and now it is time for God to bring about a period of peace and happiness, as stated in the first stanza:

Lord, bless us, Hungarians with good cheer and harvest;

Shield and save us when we are pressed by foes the hardest! After storms of bygone days favour our endeavour; sins of future, sins of past are atoned forever.

(Translated by Watson Kirkconnell and Earl M. Herrick)

[Isten, áldd meg a magyart

Jó kedvvel, böséggel,

Nyújts feléje védö kart,

Ha küzd ellenséggel;

Bal sors akit régen tép,

Hozz rá víg esztendöt,

Megbünhödte már e nép

A multat s jövendöt!] 
Kenyeres, János. "Manifestations of Hungarian Identity in Literature.” Hungarian Cultural Studies. e-Journal of the American Hungarian Educators Association, Volume 12 (2019) DOI: 10.5195/ahea.2019.347

Although the Hungarian Parliament passed a law declaring the Hymn as the national anthem of Hungary in 1903, this law was never enacted by Franz Joseph I. The poem only became the official anthem of Hungary with the regime change in 1989, when a new version of the Constitution was adopted.

The "Hymn" by Kölcsey was by no means the first national anthem in the history of Hungary, but rather the first one shared by the whole nation. Its literary predecessors are religious pieces, such as the Catholic "Boldogasszony Anyánk" ['Blessed Virgin Mary, Our Mother'], a folk hymn whose earliest written version goes back to the 1715 hymnal composed by Demeter Szoszna, a Benedictine monk. Addressed to the Virgin Mary, its refrain reads: "Magyarországról, édes hazánkról, / ne feledkezzél el szegény magyarokról." ['Do not forget Hungary, /Our Sweet homeland, the poor Hungarians.' $]^{2}$ Another literary piece which served as a Catholic national anthem is "Ah, hol vagy, magyarok tündöklo" csillaga" ['O, where are you, shining star of Hungarians'], a hymn to St. Stephen that is still sung in churches to date. This work became a folk hymn at the time when Maria Theresa had the Holy Right brought back to Hungary in 1711 from Raguza (Dubrovnik). A Protestant folk hymn traces its origins to Psalm 90 in Theodore Beza's Genevan Psalter which was translated by Albert Szenczi Molnár and published in 1607. It begins with the line, "Tebenned bíztunk eleitöl fogva" ['We trusted in you from the very beginning'], and is a prayer of Moses, the man of God. According to tradition, Bocskai's hajdu's sang this song when they went to war. Mention should also be made of the "Rákóczi-nóta" ['Rákóczi Song'], later transformed into the "Rákóczi March," which also functioned as an unofficial anthem of Hungary. Created around 1730, this song is a lament depicting the hardships of Hungarians under Habsburg rule.

While Kölcsey's "Hymn" has some important literary predecessors, a few other texts have assumed a quasi-national anthem status alongside it. The first of these to be mentioned is Mihály Vörösmarty’s "Szózat” ['Appeal'], written in 1836, which begins with these verses:

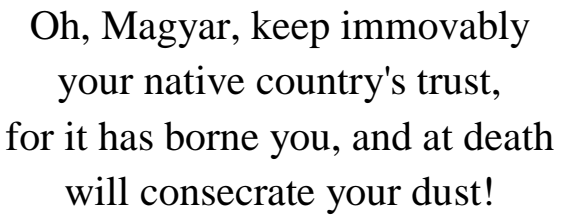

\footnotetext{
${ }^{2}$ Unless otherwise noted, all translations are by the author.
} 
Kenyeres, János. "Manifestations of Hungarian Identity in Literature.” Hungarian Cultural Studies. e-Journal of the American Hungarian Educators Association, Volume 12 (2019) DOI: 10.5195/ahea.2019.347

\author{
No other spot in all the world \\ can touch your heart as home- \\ let fortune bless or fortune curse, \\ from hence you shall not roam! \\ (Translated by Watson Kirkconnell) \\ [Hazádnak rendületlenül \\ Légy hive, oh magyar; \\ Bölcsöd az s majdan sírod is, \\ Mely ápol s eltakar. \\ A nagy világon e kivül \\ Nincsen számodra hely; \\ Áldjon vagy verjen sors keze; \\ Itt élned, halnod kell.]
}

(1836)

In contrast to the "Hymn," the "Appeal" is not a prayer and its main idea is that one should be loyal to his or her homeland to the very last, no matter the cost. Whereas the "Hymn" creates a sense of belonging to the nation based on common roots, history and national successes and failures, in the "Appeal" the emphasis is placed on the shared obligation of Hungarians. The "Appeal" depicts the great periods of Hungarian history (represented by Árpád and Hunyad), including national calamities and the tremendous human losses, and claims that there must be a happy period coming at long last, as all the suffering cannot have happened in vain:

\author{
It cannot be that all in vain \\ so many hearts have bled, \\ that haggard from heroic breasts \\ so many souls have fled! \\ It cannot be that mind and strength \\ and consecrated will \\ are wasted in a hopeless cause \\ beneath a curse of ill! \\ (Translated by Watson Kirkconnell)
}


Kenyeres, János. "Manifestations of Hungarian Identity in Literature.” Hungarian Cultural Studies. e-Journal of the American Hungarian Educators Association, Volume 12 (2019) DOI: 10.5195/ahea.2019.347

\author{
[Az nem lehet hogy annyi szív \\ Hiában onta vért, \\ S keservben annyi hü kebel \\ Szakadt meg a honért. \\ Az nem lehet, hogy ész, erö, \\ És oly szent akarat \\ Hiába sorvadozzanak \\ Egy átoksúly alatt.]
}

The poem also reckons with the possibility of the death of the nation, as a huge grave appears while fellow nations look on in tears.

The concerned aspect of the "Hymn" and the "Appeal" is a feature that should be noted with emphasis, as it is exactly this attitude which makes them topical today. Having said this, there are situations in which the original message and the current context clash. Thus, people living outside of the borders of Hungary, some of whom have multiple national identities, often find it paradoxical that - according to the "Appeal" - they should "live and die" in the homeland (or, as Watson Kirkconnell's translation goes: "from hence [they] shall not roam.”). Also, knowing that a significant number of young people have left Hungary in the past decades and will presumably do so in the future, the singing of the "Appeal" at graduation ceremonies in high schools and universities in Hungary assumes a touch of irony these days. Nevertheless, even though some of the nineteenth-century romantic ideas and images invoked in these poems sound antiquated and archaic today, these texts remain forceful manifestations of national identity. Today, in an age of irony, a mental state characterized by the absence of definite frames of reference, the language of these poems, full of pathos related to the aesthetic category of the sublime, sounds remote. At the same time, this feeling of remoteness usually mingles with a sense of affection and nostalgia for the ideals of an age left behind.

When discussing the national anthem, mention should also be made of the "Székely Himnusz ['Székely Hymn']. Written by György Csanády with its music composed by Kálmán Mihalik in 1921, this post-Trianon text references Csaba királyfi ['Prince Csaba'], a legendary hero of the Székelys. Its well-known lines read: "Ne hagyd elveszni Erdélyt, Istenünk!" ['Do not let Transylvania be lost, our God!'] Since the regime change in 1989, the "Székely Hymn" has often been sung during celebratory occasions, whether in Hungary or Hungarian communities outside Hungary, including the Hungarian diaspora, a phenomena marking how national belonging extends beyond the borders of the country in the eyes of many.

The fact that Hungarians have more than one text (the "Hymn," the "Appeal" and, recently, the "Székely Hymn") assuming the status or quasi-status of a national anthem indicates the multiplicity of Hungarian identity. These texts become part and parcel of Hungarian identity due to the frequency with which individuals encounter them from their early childhood on. Of course, this is true of the link between the national anthem and national identity of other nations, 
too; in the case of Hungarian identity this connection is coupled with a strong Hungarian literary canon which plays an important role in identity building. In the absence of a solid literary canon, literary works are less significant in the identity structure of many other nations; in larger countries a diversity of texts are taught at schools due to substantial regional differences. In contrast, the Hungarian school system has traditionally placed and still places emphasis on a stable and only slowly changing literary canon. Although it is not the most popular task among schoolchildren, the tradition of having to memorize literary texts at school eventually leads to a body of texts known by most members of society.

Even though a critical attitude was present throughout the Reform Age, this was a hopeful period during which nation-building and the improvement of the political and economic conditions were among the core issues that were advocated. The brief period of the 1848/49 revolution was also a time for general optimism, most famously exemplified by Sándor Petőfi's népies ['folk-like'] patriotic poetry. To this day, Petöfi's fascinating poems describing the Hungarian countryside, his political poems expressing his radical, revolutionary ideas, his descriptions of everyday people and his technical skill hidden beneath the veil of an unpretentious, fresh vernacular that lends the impression of the spontaneity associated with everyday speech are appreciated and even admired. It is sufficient to think of his poems, "Nemzeti dal," ['National Song'], "Föltámadott a tenger" ['The Whole Sea Has Revolted'] or "Magyar vagyok" ['I Am a Magyar'] to demonstrate his attachment to the homeland; the latter poem also reveals a high degree of concern, criticism and exhortation regarding the conditions around him:

A Magyar I! But what is that to-day?

Ghost of a glorious past that restless stirs

At dark, but which the midnight spells must lay

In dreamless sleep down in his sepulchres.

$$
[\ldots]
$$

A Magyar I! But o! how I deplore

To be a Magyar now! It is a shame

That while the sun in brightness shines all o'er

No gleam of dawn to us as yet there came;

Still all the wealth on earth could not suffice

My love of thee, dear spot, e'er to efface

Dear native land, I still must idolize

And love thee still, in spite of thy disgrace!

(Translated by WM. N. Loew) 
Kenyeres, János. "Manifestations of Hungarian Identity in Literature.” Hungarian Cultural Studies. e-Journal of the American Hungarian Educators Association, Volume 12 (2019) DOI: 10.5195/ahea.2019.347

[Magyar vagyok. Mi mostan a magyar?

Holt dicsöség halvány kisértete;

Föl-föltünik s lebúvik nagy hamar

- Ha vert az óra - odva mélyibe.

$$
[\ldots]
$$

Magyar vagyok. S arcom szégyenben ég,

Szégyenlenem kell, hogy magyar vagyok!

Itt minálunk nem is hajnallik még,

Holott máshol már a nap úgy ragyog.

De semmi kincsért s hírért a világon

El nem hagynám én szülöföldemet,

Mert szeretem, hön szeretem, imádom

Gyalázatában is nemzetemet!]

(1847)

This poem echoes Dániel Berzsenyi's earlier poem, "A magyarokhoz" ['To the Hungarians'], written in a tone of similar anger about his own, beloved nation:

Oh you, once mighty Hungary, gone to seed, can you not see the blood of Árpád go foul, can you not see the mighty lashes

heaven has slapped on your dreary country?

[...]

What are Hungarians now?! Sybaritic wrecks

(Translated by Adam Makkai)

[Romlásnak indult hajdan erös magyar!

Nem látod, Árpád vére miként fajúl?

Nem látod a bosszús egeknek

Ostorait nyomorúlt hazádon?

[...]

Mi a magyar most? - Rút sybaríta váz.]

(1810)

The romantic and hopeful period during the first half of the nineteenth century was followed by one of depression and resignation after the crushed revolution of 1848-1849, when the very act of resistance was regarded an ethical act. János Arany's "A walesi bárdok" ['The Bards of Wales'] represents this kind of resistance steeped in resignation. The genesis of the poem is well-known: Arany was asked to write a poem in praise of Franz Joseph on the occasion of the latter's visit to Hungary in 1857 . The poet refused the request, referring to his failing 
health, but started writing the poem in 1857, then completed it in 1861. Arany's own note explains the context of the poem: "Although doubted by scholars, it is strongly held in the oral tradition that King Edward I of England had five hundred bards executed after his conquest of Wales in 1227, lest they incite the Welsh youth to rebellion by reminding them of their nation's glorious past in their songs" (Makkai 2000: 319) ['A történelem kétségbe vonja, de a mondában erősen tartja magát, hogy I. Eduárd angol király, Wales tartomány meghódítása (1277) után, ötszáz walesi bárdot végeztetett ki, hogy nemzetök dicső múltját zöngve, a fiakat föl ne gerjeszthessék az angol járom lerázására’ (Keresztury 1955: 372)]. Whether the poem is based on a historical event or not is less relevant for the purpose of this paper compared to Arany's conviction concerning literature and art's power to arouse national sentiments. The poem has a strong allegorical meaning that alludes to the passive resistance of Hungarians to Habsburg rule while simultaneously underscoring the need to proclaim the truth:

"Lo, here I stand, at your command,

To chant your deeds, O king!”

And weapons clash and hauberks crash

Responsive to his string.

"Harsh weapons clash and hauberks crash, And sunset sees us bleed, The crow and wolf our dead engulf -

This, Edward, is your deed!

"A thousand lie beneath the sky, They rot beneath the sun, And we who live shall not forgive This deed your hand hath done!"

(Translated by Watson Kirkconnell)

[Itt van, király, ki tetteidet

Elzengi, mond az agg;

S fegyver csörög, haló hörög

Amint húrjába csap.

„Fegyver csörög, haló hörög, A nap vértóba száll, Vérszagra gyül az éji vad: Te tetted ezt, király! 
Levágva népünk ezrei,

Halomba, mint kereszt,

Hogy sírva tallóz aki él:

Király, te tetted ezt!']

$$
(1857-61)
$$

It was this sentiment of strong resistance combined with the realization of the need to make pragmatic compromises which led to the Appeasement of 1867, launching one of the best and most prosperous periods of Hungarian history up until the First World War.

Concern for the homeland, however, can also be expressed by using irony, a typical feature of Kálmán Mikszáth's anecdotal style. In his novel, Új Zrínyiász ['New Zrínyiad'] (1898), a full-blown satire of both sixteenth and nineteenth century Hungary, the captain of Szigetvár and his soldiers (who made a heroic sortie from the fortress to fight the Turks in 1566) rise from the dead to find themselves in nineteenth-century Hungary. Surprisingly good at adapting to the business world of Budapest, the mighty feudal lord becomes the director of a bank while maintaining his ruthless medieval ways; the result is an absurd satire of both the mercenary business world and corruption during the nineteenth century and the dictatorial ways of the Middle Ages.

The use of irony was in fact quite common in nineteenth-century literature; Petöfi's poem "Pató Pál úr" ['Mr. Pató'] (1847) is another, earlier example of the device, where the protagonist delays with everything (getting married, making repairs to his crumbling house, maintaining his household, and even avoiding wearing shabby clothes), saying: “'Ej, ráérünk arra még” ['What's the hurry, wait and see']. The last stanza summarizes the gist of the message:

He has squandered all the fortune that his fathers left behind, he has lost the land, the livestock, property of every kind.

Do not blame him. All Hungarians are born to procrastinate. It's his noble nation's motto:

"What's the hurry, wait and... wait."

(Translated by Peter Zollman) 
Kenyeres, János. "Manifestations of Hungarian Identity in Literature.” Hungarian Cultural Studies. e-Journal of the American Hungarian Educators Association, Volume 12 (2019) DOI: 10.5195/ahea.2019.347

\author{
[Életét így tengi által; \\ Bár apái nékie \\ Mindent oly böven hagyának, \\ Soha sincsen semmije. \\ De ez nem az ö hibája; \\ Ö magyarnak születék, \\ S hazájában ösi jelszó: \\ "Ej, ráérünk arra még!"]
}

(1847)

In contrast to the new waves of literary expression, including the népies ['folk-like'] style or the satire, in the second part of the nineteenth century Petöfi's landscape poetry was often imitated in folksy, largely empty diction that implied a lazy, sleepy sense of a national belonging filled with nothing more than a vacuum. This type of popular poetry was epitomized by Mihály Szabolcska, of whom Zsigmond Móricz wrote the following harsh lines in 1930: "This was his calling: to cast the babble of being satisfied with everything over a world which languished in drowsy simplicity. He was rich because he was unambitious and delighted because he had no thoughts" ['Ez volt a hivatása: ráborítani a mindennel megelégedés gügyögését arra a világra, amely álmos együgyüségben tengette napjait. Gazdag volt, mert igénytelen, boldog, mert gondolattalan'] (Móricz 1930: 717).

Before moving on to the twentieth century, however, we must stop here for a moment. Identity, the notion of being identical with oneself, also entails the concept of difference: we are who we are because we are not them. Hungarian assumes its meaning by its difference from those who are not Hungarian. What this difference means is highly problematic if one tries to define it, but the concept of difference or opposition is an integral part of the concept. Hence there is this duality of we and they. In history, the "other" has often been an external enemy, as in they, the ones who tried to invade us; and they often did. Hungarian history is frequently marked by invasions: the Mongolian invasion, which lasted for only a few months, followed by the enormous devastation of the Turkish occupation which dragged on for 150 years and then the Habsburg age, which coexisted with Ottoman rule only to replace it. Unfortunately, the external enemy has often been combined with the concept of the internal enemy, whether it was the kuruc-labanc ['revolutionary, true Hungarian-collaborator, German sympathizer'] dichotomy, the national-urban opposition (often a euphemism for Hungarians contra Jews) or the conflict between those from the working class, the proletariat and peasantry, as opposed to those who are not, such as the rich peasants, the kulaks, or the aristocracy. It is hard to say whether an external enemy or the concept of an internal enemy is more destructive; both proved to be physically and spiritually harmful and both have occurred in quick succession throughout Hungarian history from the time of Mohács (when János Szapolyai failed to arrive in time to help King Louis II against Suleiman the Magnificent) to the present day. 
Kenyeres, János. "Manifestations of Hungarian Identity in Literature.” Hungarian Cultural Studies. e-Journal of the American Hungarian Educators Association, Volume 12 (2019) DOI: 10.5195/ahea.2019.347

The concept of identity as a theoretical category has been the focus of heated debates during the past few decades. It has been a matter of interest for literary and cultural studies and has been discussed in the field of postcolonial, ethnic and feminist criticism (to name but a few) from viewpoints ranging from psychoanalytic through poststructuralist to cultural theories. Traditionally, the predominant concept of identity has been associated with essentialism, the notion that individuals or groups of individuals have a fixed and recognizable "essence" by which they can be readily classified. According to this view, individuals belong to an invariable and determinate category, such as class, race, gender, or nation. As Satya P. Mohanty asserts, "Simply put, the essentialist view would be that the identity common to members of a social group is stable and more or less unchanging, since it is based on the experiences they share" (Mohanty 1997: 202). This idea that individuals or groups of individuals have a fixed, stable and recognizable "essence" by which they can be classified has been challenged and substantially undermined by postmodern, especially poststructuralist, critics. To illustrate the heat of the debates and their result, it is sufficient to refer to Paula M. L. Moya's observation that "much of what has been written about identity during this period seeks to delegitimate, and in some cases eliminate, the concept itself by revealing its ontological, epistemological, and political limitations" (Moya 2000: 1-2).

Speaking of Hungarian identity, essentialism was already rejected by Hungarian thinkers as early as 1939, when the volume Mi a magyar? was published. As Babits claimed:

Our national vanity prompts us to see particularly Hungarian traits in all that is valiant, noble and appealing. It is most convincing and reassuring to seek the national character in a simple, patriarchal, and naturally dignified conduct and mentality... This entire train of thought presents itself so naturally that it occurs with respect to practically every people, as self-evident. This is why almost every nation likes to describe its own ideal characteristic type with similar traits. The Hungarian is hospitable, chivalrous, pugnacious, proud, fearless and sincere. But if I ask a Castilian or a Serb, without doubt he too will be hospitable, chivalrous, pugnacious, proud, fearless and sincere. As will the Arab. And the Japanese. All claim a right to these primitive virtues. (Babits 2018: 93)

[Nemzeti hiúságunk arra ösztönöz, hogy mindenben, ami derék, nemes és rokonszenves, különlegesen magyar vonást lássunk. [...] Ez az egész gondolatmenet annyira kínálkozó, hogy úgyszólván minden népnél egyforma magátólértetőséggel merül föl. Ez okozza, hogy majdnem minden nemzet a saját eszményien jellegzetes típusát hasonló vonásokkal szereti rajzolni. A magyar vendégszerető, lovagias, harcias, büszke, bátor és nyílt. De ha megkérdem a castiliait vagy a szerbet, egészen bizonyosan az is vendégszeretö, lovagias, harcias, büszke, bátor és nyilt. Söt a japán vagy az arab is ilyen. Valamennyi jogot formál e primitív erényekre.] (Babits 1939: 47-48.) 
Kenyeres, János. "Manifestations of Hungarian Identity in Literature.” Hungarian Cultural Studies. e-Journal of the American Hungarian Educators Association, Volume 12 (2019) DOI: 10.5195/ahea.2019.347

Therefore, rather than using what are called essentialist notions today, Babits proposes that each and every feature of the Hungarian character that has presented itself over history should be considered when talking about Hungarianness. Furthermore, he also believes that Hungarianness has evolved historically and is an intellectual phenomenon, not a bodily one: "The hereditary transmission that ensures its continuity is not bodily but spiritual... Hungarians have always been a mingling people ever since Saint Stephen, and surely had been even before” ['Az átöröklés, mely folytonosságát biztosítja, nem testi, hanem lelki. [...] a magyar kevert és állandóan keveredő nép, Szent István óta s egész bizonyosan már azelőtt is'] (Babits 2018: 82; Babits 1939: 38). Babits compares the evolution of Hungarianness to a plant; in each of its stages of development it keeps something of its essence and its overall essence comprises this whole development. Another image he uses is this: Hungarianness has a thousand faces, spread out both in time and space, and that which is Hungarian is a totality of all these very different, often opposing features. Thus, Babits rejects the idea that ancient characteristics would be more genuine than later ones: "Ancient and rudimentary traits are of no greater significance here than later ones" ['Az ősi és kezdetleges vonásoknak semmivel sincs itt nagyobb jelentőségük, mint a későbbieknek'] (Babits 2018: 95; Babits 1939: 49), as he asserted.

The tendency to focus on the ancient, the ancestral strength deriving from the Hungarian people was a feature not only of nineteenth-century poets, but also an important group of writers belonging to the népi írók ['populist writers'] movement of the early twentieth century whose world was represented by Zsigmond Móricz, Dezső Szabó, László Németh, János Kodolányi, Pál Szabó, Géza Féja and Gyula Illyés, among others. Diverse as they were, a general feature of these writers was that they viewed themselves as the authentic voice of Hungarian peasantry. As they turned against the idealizing, folkloristic attitudes of the late nineteenth century, such as those characterized by Szabolcska, they set as their goal the task of describing the harsh reality, social problems, poverty and plight of Hungary's peasantry. The népi ['populist'] writers represented a major current within Hungarian literature from the early decades of the twentieth century and their ideas could lean both left and right in the political sense. While being committed to the cause of Hungarian peasants and advocating the improvement of their social and economic conditions, these writers were far from idealizing the life of Hungarian peasantry and faithfully portrayed the backward and often primitive behaviour of these largely uneducated or otherwise underprivileged people.

In his sociological work Puszták népe ['People of the Puszta'] (1936), Illyés, for example, exposed the century-old subjugation of Hungarian peasantry. His dark but sadly realistic descriptions of the poor and dispossessed, the landless serfs of the countryside, had shown a hitherto unknown world. He was not only critical of the conditions they were forced to live in, but also saddened by the submissive attitudes they had to adopt over the centuries and their self-humiliating exaggerated respect for those who had oppressed them. In Puszták népe Illyés makes the following striking remark: "The people of the Puszta, I know this from my own experience, the experience I perceived upon myself, is a subservient nation” ['A puszták népe, 
Kenyeres, János. "Manifestations of Hungarian Identity in Literature.” Hungarian Cultural Studies. e-Journal of the American Hungarian Educators Association, Volume 12 (2019) DOI: 10.5195/ahea.2019.347

tapasztalatból, saját magamon észlelt tapasztalatból tudom, szolganép’] (Illyés 2003: 9). Illyés then goes on to explain that the landless poor surfs of the Puszta had no choice but to adopt and follow this submissive, self-humiliating behaviour towards those who had control over them in order to survive throughout the centuries.

This idea had already been present in the poetry and prose of Endre Ady, one of the most innovative and influential writers of Hungarian modernism. A lesser known short story by him entitled "Nyomorék Tar Pista" ['Cripple Pista Tar'] (1906) describes a village of subdued Hungarian peasants whose daughters or future wives are taken to the palace and sexually abused by the local landlord and his company at the annual festival. Nobody in the village even dares to think about what is happening to the girls; everyone casts his or her eyes to the ground and goes to bed. It is only the cripple of the village, Pista, who sneaks into the palace and, seeing what the lords are doing to the girls, sets the place on fire. The short story's ending shocks the reader: the landless serfs, the fellow-workers capture Pista, beat him until he is half-dead and deliver him to the landlord to be imprisoned. The contrast between this image and that of a nation of uprising and revolt is enormous.

I cannot do full justice to Ady's complex ideas concerning Hungarianness within the scope of this analysis: his work represents an unprecedented degree of tension created by his concern and love for his country, his commitment to Hungary, his constant reference to Hungarian history with its rich past and available remnants of Hungarian mythology, his strong adherence to his doomed nation, his realization of the backwardness of his own age, his descriptions of the painful social and economic problems around him, his intense desire for a change, his search for God, his radical liberal views brought from the West, and his vision of a better tomorrow, all presented with the finest artistic ingenuity. Ady embraced an unparalleled spectrum of Hungarian tradition. His essay entitled "Ismeretlen Korvin-kódex margójára" ['For the Margins of an Unknown Corvinus Codex'] (1905) depicts Hungary as a ship constantly drifting between the shores of the East and the West, unable to anchor. Ady finds this extremely tragic and claims that Hungary would be able to achieve great things if it could only find its home in Western ways and traditions. The essay suggests that the way out of this predicament would be to turn towards the West, a step that would bring fresh and democratic ideas and prosperity, compared to the wish of many of his contemporaries who were mired in the revival of the myth of an ancient, eastern Hungary. Ady voted for the West (he contributed to the journal Nyugat ['West'] from its very inception); however, for him this was not simply an either/or dilemma, but rather a question of both/and while cherishing and adhering to the best traditions of the past and simultaneously adopting the fresh and new intellectual ideas coming from the West.

Ady's belief in the need to integrate tradition with new ideas from the West stems from an intellectual approach which was shared much later by Babits in the 1939 Mi a magyar? volume as well. Babits holds that with the passage of time Hungarianness, which he considers a living intellectual phenomenon, "becomes increasingly rich, diverse and different" ['egyre 
Kenyeres, János. "Manifestations of Hungarian Identity in Literature.” Hungarian Cultural Studies. e-Journal of the American Hungarian Educators Association, Volume 12 (2019) DOI: 10.5195/ahea.2019.347

gazdagabbá s sokszínübbé válva jobban elkülönböződik’] (Babits 2018: 95; Babits 1939: 49) from its primitive state. Moreover, he also observes that,

As peasant culture is more international than high culture, the lifestyle of simple peasants cannot be more characteristically national than that of the noble classes. On the contrary: the life of primitive folk shows surprisingly uniform traits everywhere and differs only in costumes and externalities rather than in character and thinking. The peasants of Maupassant are not so far from the peasants of Zsigmond Móricz. (Babits 2018: 95)

[Ahogy a parasztkultúra nemzetközibb a magas kultúránál, úgy az sem áll, hogy az egyszerü parasztság élete jellegzetesebben nemzeti volna, mint az úri osztályoké. Ellenkezöleg, a primitív népélet mindenütt meglepöen egyforma vonásokat mutat, $s$ inkább csak viseletben s külsöségekben különbözik, mint jellemben és gondolkodásban. Maupassant parasztjai nincsenek olyan messze a Móricz. Zsigmond parasztjaitól.] (Babits 1939: 49)

Babits explains that we often confuse the rustic with the Hungarian, despite the fact that folk tales show a striking similarity around the globe. Moreover, he asserts that high culture is full of external influences that also follow Western models. The late eighteenth- and early nineteenth-century poet Dániel Berzsenyi's expression of loyalty to the homeland, for example, is based on Latin models, especially Horace (Babits 1939: 47-48).

Just like the other contributors to the 1939 Mi a magyar? volume, Babits rejects the concept that Hungarianness can be identified as a racial or ethnic feature: "It is by no means some bodily or tribal characteristic which can be inherited physically... Petöfi, who was not purely of Hungarian stock, says more to me in this respect than the grey matter of all the anthropologists combined" ['Semmi esetre sem valami testi vagy törzsi jelleg, fizikailag örökölhető. [...] Petőfi, ki nem is volt tiszta magyar faj, többet mond nekem erre nézve, mint az antropológusok minden koponyái'] (Babits 2018: 82; Babits 1939: 37-38). He also adds: "We...do not feel Kölcsey's soul to be any more eastern than that of Petőfi's, whose family were not direct descendants of Lord Ete" ['Mi [...] semmivel sem érezzük a Kölcsey lelkét például keletibb hőfokúnak, mint a Petőfiét, akinek családja nem származott az Ete vezér egyenes neméböl'] (Babits 2018: 100; Babits 1939: 54). In 1939, this was a strong stance that opposed the racial ideology of the age.

Mentioning Petőfi as an outstanding representative of Hungarian poetry despite his specific ancestry leads us to examine another influential theory which appeared in the same year, notably László Németh's concept of the hígmagyar ['thin Magyar'] and mélymagyar ['deep Magyar'] as expounded in his essay Kisebbségben ['In Minority'] (1939). This binary opposition has stirred a lot of controversy ever since it was published. Although Németh did not define these concepts clearly and his distinction between a "deep Hungarian" and "thin Hungarian" was more of a spiritual nature that of a racial one, he regarded assimilation as something of a 
Kenyeres, János. "Manifestations of Hungarian Identity in Literature.” Hungarian Cultural Studies. e-Journal of the American Hungarian Educators Association, Volume 12 (2019) DOI: 10.5195/ahea.2019.347

detriment, in that it prevented one from being "deep Hungarian.” In his essay, after acknowledging Petőfi's exceptional talent and excellence as a poet, Németh questioned Petőfi's Hungarianness in the form of a seemingly laudatory question: "And even though we did not feel that we could learn Hungarianness from Petoffi, could we have found a greater teacher for our humanity than he?” ['S ha Petőfit nem is éreztük olyannak, akitől magyarságot lehet tanulni, emberségünknek találhattunk-e nagyobb iskolát?' (Németh 1989: 423)]. Then he adds: "It is another issue whether Petöfi reached down to the Hungarianness whose slow sinking we can follow beneath a suddenly rising literary Hungarianness. No; he did not know about this Hungarian Atlantis. He never felt the bitter labour pains of the Hungarian language and rhythm" ['Más kérdés, hogy Petőfi leért-e igazán ahhoz a magyarsághoz, melynek a lassú elsüllyedését egy hirtelen támadt irodalmi magyarság alatt nyomon követjük. Nem - ő erről a magyar Atlantiszról nem tudott. Magyar nyelv és ritmus keserves szülőfájásait sosem érezte' (Németh 1989: 423)].

Although Németh did not directly address political questions, the suggestions in his essay in 1939 were either short-sighted or far from being decent, especially in the context of the Jewish laws of the time. Németh's essay has been subject to criticism to date. Some critics show more understanding towards him and claim that he was merely against some shallow concepts of Hungarian identity. Although he should have used other terms instead of "deep Hungarian" and "thin Hungarian" to avoid being misunderstood, what he seems to have meant was that an old Hungarian tradition had been lost, or retained only by some (Zsigmond Kemény, János Vajda, Károly Zilahy, Endre Ady, Zsigmond Móricz, as opposed to Ferenc Kazinczy, József Eötvös and Sándor Petőfi), and he was against jingoism, the big-mouthed displays of Hungarianness (Hellenbart 2009). Other critics condemn Németh's division of writers as it had an extremely damaging effect on Hungarian intellectual life (Fábri 2009). Németh himself realized the ambiguity of his categories and in 1942 claimed that he himself was a "thin Hungarian" on his mother's side and a “deep Hungarian” on his father's (Németh 2014). Despite this controversial theory, Németh's supreme value as a novelist is beyond doubt, similar to his genuine ideas in his other theoretical works.

But why were questions of Hungarianness so important? The answer lies in the fact that the First World War and the Trianon Peace Treaty of 1920 were among the greatest traumatic experiences in twentieth-century Hungarian history, the fallout of which determined the lives of entire generations. With the casualties, loss of lives and two-thirds of the country's territory and 3.3 million Hungarians finding themselves outside the new borders, the shock for the country was enormous. Literature and culture fell into many parts, described by Gyula Illyés as the fivepointed fife (Hungary, Transylvania, the Southern Land, Upper Hungary and Western émigré literature). With this background, it was natural that the question of national identity became central during the coming decades. With so much lost, intellectuals were increasingly preoccupied with the question of what was Hungarian and literature also responded in its own way. Edited by Dezső Kosztolányi, the anthology Vérzö Magyarország - Magyar írók 
Kenyeres, János. "Manifestations of Hungarian Identity in Literature.” Hungarian Cultural Studies. e-Journal of the American Hungarian Educators Association, Volume 12 (2019) DOI: 10.5195/ahea.2019.347

Magyarország területéért ['Bleeding Hungary: Hungarian Writers for the Territory of Hungary'] (1921), containing the work of Árpád Tóth, Zsigmond Móricz, Gyula Krúdy, Frigyes Karinthy, and Mihály Babits (among many others), was the first book to examine the topic. In a sense almost all literature between the two World Wars was impacted by this trauma and its consequences.

Having said this, some left-wing writers had to leave the country for political reasons during the interwar period while some ideas that were regarded as immoral ended up getting their authors into trouble. For example, Attila József was famously expelled from the University of Szeged for his poem "Tiszta szívvel” ['With a Pure Heart']. The poem begins with these lines:

$$
\begin{aligned}
& \text { Without father without mother } \\
& \text { without God or homeland either } \\
& \text { without crib or coffin-cover } \\
& \text { without kisses or a lover } \\
& \text { (Translated by Tamás Kabdebó) } \\
& \text { [Nincsen apám, se anyám, } \\
& \text { se istenem, se hazám, } \\
& \text { se bölcsöm, se szemfedöm, } \\
& \text { se csókom, se szeretőm.] }
\end{aligned}
$$

The poem is a perfect example of the solitude of the twentieth-century man, a condition in which neither a national community nor a relationship between two people can be conceived, either. Yet, the poem also combines tones of playfulness: "I sell all my twenty years. // Perhaps, if no one else will / the buyer will be the devil." ['húsz esztendőm eladom. // Hogyha nem kell senkinek, / hát az ördög veszi meg.'] His other poems, on the other hand, witness a complex attachment to the homeland, uncovering the individual's struggle to belong somewhere against the backdrop of an indifferent world, whether set in urban landscapes or in the countryside, as witnessed in his poem “A Dunánál” ['By the Danube'].

A special case of patriotism is provided by the life and work of Miklós Radnóti, who was murdered in the Second World War as a conscript to labour service. His poems express a tender affection for the homeland and the ones left behind from the perspective of the horrors of the war. The paradox of being ousted from the nation and still inseparably belonging to it is also present in the Nobel Prize-winning writer Imre Kertész's novel Sorstalanság ['Fatelessness'] (1975), in which the protagonist is ridiculed by his fellow prisoners in the concentration camp for being a Hungarian, whereas he is in the camp exactly because he has been deprived of his Hungarian identity at home, yet he could explain this complex problem to those making fun of him only in his native Hungarian language (Kertész 1993: 158). 
Following the Second World War and the subsequent Soviet occupation, the issue of Hungarian identity became by and large taboo, as nothing that could potentially arouse nationalism and revisionism was allowed to be directly addressed. Authors often resorted to the old tactics of placing a message between the lines and moral questions could be discussed. Writers unwilling to support communist ideology receded into the inner spheres of art. Nevertheless, literature was able to express common experiences, such as the ills of the modern world, alienation and the search for truth. Within this context, serious and sincere literature was able to arise, including János Pilinszky's poetry, which can be interpreted as the living consciousness of the nation. Stemming from a Catholic background, his poetry depicts the terrible world of the twentieth century with unparalleled force, including death permeating the victims of the war. His poetry is saturated with immense sadness over the incomprehensible destruction of the past cataclysm. "Harbach 1944" describes a march towards death, represented by a concentration camp:

Silence accepts their frames. Each face

is dipped in height, as if straining for the scent of troughs in the sky far off.

And like a cattle-yard prepared for the herded beasts outside its gates flung open violently death, for them, gapes wide.

(Translated by Clive Wilmer and George Gömöri)

[De törzsük már a némaságé. Magasba mártják arcukat, feszülten mintha szimatolnák a messze égi vályukat.

Mert fogadásukra már készen, akár egy megnyiló karám, kapuit vadul széttaszítva sarkig kitárult a halál.]

His other poems, such as the "French Prisoner" ['A francia fogoly'] continue the theme of heart-rending sorrow at the sight of human loss. This is literally true; in the poem, the starving French prisoner of war, who escaped from the POW camp and was searching for any scrap of food in the backyard, now claims the speaker's heart. Some of Pilinszky's other poems show that the speaker finds solace in the figure of Christ. 
Kenyeres, János. "Manifestations of Hungarian Identity in Literature.” Hungarian Cultural Studies. e-Journal of the American Hungarian Educators Association, Volume 12 (2019) DOI: 10.5195/ahea.2019.347

There were other common experiences, too, shared by the people of this period. Such was the presence of dictatorship, and Illyés's poem "Egy mondat a zsarnokságról” ['A Sentence about Tyranny'] was a ground-breaking achievement in describing how the mechanism employed by dictatorship affected the individual. Written in 1950 in the darkest days of the Rákosi regime but remaining unpublished until November 2, 1956, the poem depicts the nature of tyranny as it spreads to everything and everyone, finally engulfing the individual and the human soul. Even though it was written in 1950, the poem is generally considered to be one of the most outstanding literary monuments of the 1956 Revolution and presents a rare example of poetry's ability to evoke an essential element of the shameful predicament and identity of a whole generation.

The 1956 Revolution was largely treated by silence in literature. Although some novels and dramas discussing 1956 appeared soon after the revolution, these expressed the interests and requirements of Communist propaganda. However, the metaphorical language of poetry, sophisticated, but unmistakable allusions in prose, the absurd or grotesque were literary tools in the hands of writers to recall the days of the freedom fight. Déry's novel G. A. úr X-ben ['Mr. A.G. in X'] (1964) uses Kafkaesque absurd to this end while a similar technique is employed in Ferenc Karinthy's novel Epepe (1979), published in English as Metropole, and István Örkény’s drama Pisti a vérzivatarban ['Stevie in the Bloodbath'] (1983). Although these works had an elusive, intangible storyline, each of them had to wait years before being given the green light for publication. In the second half of the 1980s, with the rapidly changing political system and the eventual collapse of communism, all political and ideological obstacles were removed from the path of discussing the memory of the 1956 revolution. A number of works have been published since, drawing on the theme of the revolution (for more information on 1956 in literature, see J. Kenyeres 2011a).

With the change in regime, a new situation arose with its own problems which literature deems it its task to discuss. In 2005, a new volume entitled Mi a magyar? was published to commemorate the 1939 volume, with the participation of contemporary intellectuals. Most of the articles in the volume commented on the outdated nature of national characterology and found that, as relevant as it was, the question was extremely hard to answer in unambiguous terms. Péter Esterházy's approach may be astounding at first:

I am Hungarian. What do I care for the art of Hungarianness as such $?^{3}-$ What is the Hungarian? I am not interested, I don't give a damn. If I am not interested in something it is what the Hungarian is. Just like I don't get excited about what the

\footnotetext{
${ }^{3}$ Esterházy's text here invokes the first two lines of Attila József's poem "Ars poetica": "I am a poet - what do I care / for the art of poetry as such?” (translated by Michael Beevor) ['Költő vagyok - mit érdekelne / engem a költészet maga?'].
} 
Kenyeres, János. "Manifestations of Hungarian Identity in Literature.” Hungarian Cultural Studies. e-Journal of the American Hungarian Educators Association, Volume 12 (2019) DOI: 10.5195/ahea.2019.347

Italian is, what the French is.... First there is the I, then there is the we, and not out of narcissism but because there is nothing without the I.

[Magyar vagyok, mit érdekel engem a magyarság maga. - Mi a magyar? Nem érdekel, fütyülök rá. Ha valami nem érdekel, az az, hogy mi a magyar. Amiképpen az sem izgat, hogy mi az olasz, mi a francia. [...] Elöbb van az én, azután a mi, s nem nárcizmusból, hanem mert én nélkül nincsen mi.] (Esterházy 2005: 60)

Esterházy's seemingly careless remark is in fact based upon his philosophical conviction that there is no national identity without individual identity and not even individual identity can be defined. However, in another context he also asserts, "and I care for it, moreover, this is an understatement: I cannot but care for it as far as I regard it as part of the Hungarian tradition(s), for I work and live on this tradition" [és érdekel, söt ez kevés: nem lehetséges, hogy ne érdekeljen, amennyiben ezt mint a magyar hagyomány(ok) részét tekintem, mert hisz ebböl a hagyományból dolgozom, élek (Esterházy 2005: 57)].

In his thorough analysis in the same volume, the writer Lajos Grendel from Upper Hungary suggests that Hungarian identity is still problematic due to the inability to face sincerely the causes that led to Trianon trauma. He is of the belief that instead of blaming the governments, revolutions immediately preceding the peace treaty, the mistakes of the previous decades should be admitted, such as the treatment of national minorities in pre-Trianon Hungary. According to Grendel, the inadequate treatment of national minorities in pre-First World War Hungary led to these minorities not considering Hungary their homeland. Following in the footsteps of István Bibó, Grendel also speaks about anti-Semitism and other forms of discrimination as huge obstacles in the way of making the nation come together in unity (Grendel 2005: 75-91).

At this point it should be noted that it is precisely Hungarian literature which has made some significant progress in what is usually called "reckoning with the past and the present." Soul searching is an aspect of contemporary literature, whether it is about compliance and compromises made with dictatorships or the problems of discrimination of the past and the present. Pál Závada's novel Egy piaci nap ['A Market Day'] (2016) addresses the Kunmadaras pogrom of 1946 against the Jews, Krisztián Grecsó's drama Cigányok ['Gypsies'] deals with the serial killings committed against Hungarian Roma in 2008-2009, while other works, including Virág Erdős's or János Lackfi's poetry, discuss contemporary problems, such as emigration from Hungary. Both poets use the postmodern technique of mixing lines from previous canonical Hungarian literature with contemporary slang; Virág usually achieves a tragic tone, while Lackfi tends to treat the topic with great humour. Lackfi's entertaining stories about present-day Hungarian mentality in the volume Milyenek a magyarok ('Homo Hungaricus'] (2012) and its follow-up Milyenek még a magyarok [Homo Hungaricus Again'] (2013), have gained a lot of popularity in Hungary. 
Kenyeres, János. "Manifestations of Hungarian Identity in Literature.” Hungarian Cultural Studies. e-Journal of the American Hungarian Educators Association, Volume 12 (2019) DOI: 10.5195/ahea.2019.347

An examination of patterns of Hungarian identity in literature cannot be complete without considering the perspective of authors with experiences outside of Hungary's borders. From the rich variety of available literature, in what follows I focus on two different responses.

Áron Tamási has a "cross-border" approach to Hungarian identity from at least three aspects. He was born in Farkaslaka, Harghita County, Transylvania in 1897, and professed to have a Székely-Hungarian identity. After the Peace Treaty in 1920, he found himself in Romania and emigrated to the United States in 1923. It was there that he wrote a number of his novels, including Ábel a rengetegben ['Abel Alone'] ' (1932), Ábel az országban ['Ábel in the Country'] (1933) and Ábel Amerikában ['Ábel in America'] (1934). Ábel Amerikában, the final part of the Ábel Trilogy is about the protagonist's journey to the United States. Just like the author, Ábel has a Székely (or Székely-Hungarian) identity from the very first. As Erzsébet Dani has observed, while Ábel "holds that all people are the same in a universal, democratic sense, they remain individual and sovereign, with distinct cultural identity and with the plus that individuates them and makes them personalities. But reaching the shores of America, he comes across the sameness that melting-pot ideology inspires" (Dani 2015: 152). As for his Székely identity, he claims that the Székely is "Hungarian, only even better than that" (qtd. by Dani 2015: 152). Ábel finds himself in the melting pot of America, comes across people with various backgrounds and maintains his non-discriminatory, open-minded attitude to anyone he meets. His identity does not change: he remains the same Székely (Székely-Hungarian) as he used to be, but his experiences prompt him to find the answer to the important existential question of "what is our purpose in the world" ['mi célra vagyunk a világon'] (Tamási 101). He asks numerous people, even Jesus Christ (Tamási 126), but is not satisfied with what he hears. Then, one day, he sees a black man going through a spiritual cleansing, an exorcism of sorts, in a church. When the ceremony is done, Abel is convinced that this man would be the best person to ask, now that he is free from all evil. The answer he receives is: "We are in the world to be at home somewhere in it." ['Azért vagyunk a világon, hogy valahol otthon legyünk benne'] (Tamási 128). Upon hearing this, Ábel decides to return to the Harghita. His return is smooth and natural, he finds no difficulty in readjusting: his identity as a Székely-Hungarian is steadfast and permanent.

As opposed to Ábel's effortless homecoming, Tamás Dobozy presents a much harsher reality. (The subsequent part on Dobozy is based on J. Kenyeres 2011b.) Dobozy is a secondgeneration contemporary Hungarian-Canadian writer, author of the novel Doggone (1998) and three collections of short stories, When X Equals Marylou (2002), Last Notes (2005) and Siege 13 (2012). Dobozy's story “The Inert Landscapes of György Ferenc," published in the volume Last Notes, is a powerfully written narrative about a Hungarian immigrant painter in Canada who is unable to find inspiration in North America and its landscapes. For him Canada is a big void, which can be most faithfully represented by means of applying multiple layers of white paint on

\footnotetext{
${ }^{4}$ Abel Alone is the only part of the Abel-trilogy that has been translated and published in English.
} 
Kenyeres, János. "Manifestations of Hungarian Identity in Literature.” Hungarian Cultural Studies. e-Journal of the American Hungarian Educators Association, Volume 12 (2019) DOI: 10.5195/ahea.2019.347

a white canvass, a painting he eventually completes and which, quite paradoxically, brings him some success. His alienation and estrangement from Canadian landscapes and the whole country for that matter speaks to his inner pain and loneliness, which spread to his sons (one of them the narrator), who also becomes permeated by a sense of loss and isolation. György Ferenc's attachment to Hungary is overpowering; his isolation from its landscape and culture torments him horrendously and his inability to feel at one with Canadian landscapes and Canada as a homeland develops into unspeakable loneliness. The narrator, Gergö, describes his father's pain and longing for Hungary with a sense of pathos mixed with irony. For György Ferenc fights a quixotic battle in order to maintain his Hungarian identity in a foreign land:

I remember watching him in the walk-in closet we'd converted into a studio as he closed his eyes, widened his nostrils, and moved backwards through our history to those times when he'd been allowed to stand, without guard or surveillance, on the edge of the Puszta, or the Tisza, or among the hills of the Kárpáts, and engage with the country in the act of "coexistence" that produced his paintings. (Dobozy 2005, 84)

In György Ferenc's eyes, Hungary — and by extension, Europe - is the only place where culture can possibly exist, Canada being devoid of any spirit and real culture. This short story vividly describes how György Ferenc's alienation, estrangement and loss of identity are passed on to his sons, who also become saturated with a sense of displacement and isolation. After György Ferenc dies, Ákos, one of his sons, carries his father's urn wherever he goes during his seemingly aimless wandering across Canada, which, as the narrator assumes, is in fact "in search of Hungary — not his actual home but rather the condition of being, the possibility, of home" (Dobozy 2005, 99). It is revealed only years later at the airport, when the narrator, Gergö, is about to take their father's remains back to the old homeland, that the urn is empty: the ashes were lost somewhere along the way. Ákos's attempt to cling to what he believes are his father's remains turns out to be the act of clinging to nothing.

This idea of a physical and emotional loss combined with a lost identity re-emerges at the closing of the story. It is only during his visit to Hungary when the narrator fully understands what it was for his father to "lose a country" (Dobozy 2005, 101). He realizes in Debrecen and on the Hortobágy that Hungary is no longer a frame of reference for him; it is neither his home nor homeland any longer now that his memories have been shattered by his fresh and irrefutable experience of Hungary. The ending of the story invokes an existential gaze into an abyss, with the narrator's dreadful recognition that Hungary has become a place of "infinite distance" (Dobozy 2005, 101), the void and vacuum, the nothing and emptiness being the only true realities to hold onto.

Tamási and Dobozy represent two very different manifestations of national identity: in Tamási, the protagonist finds his homeland and peace of mind, in Dobozy the characters go through a process of identity loss and are merely attached to the desire for a home, with nothing 
Kenyeres, János. "Manifestations of Hungarian Identity in Literature.” Hungarian Cultural Studies. e-Journal of the American Hungarian Educators Association, Volume 12 (2019) DOI: 10.5195/ahea.2019.347

tangible to adhere to. To conclude this study, I wish to quote from the contemporary writer Krisztián Grecsó, who has given an interview where he talks about his family, but then extends the argument to the nation:

I think if we begin to idealize the lives of our loved ones, if all the old stories are beautified and our deceased loved ones slowly receive a halo over their heads, then this will be the halo of oblivion. If you really love someone, your love will give you enough strength to accept them as they are or as they were. If you are able to recognize their motivations, weaknesses and understand the dead ends of their lives with empathy, then you will also find out why their failures became failures and why their lives evolved the way they did. In this way, you can do something with their fate. And their fate is linked to your own destiny. That is why we have a great responsibility to be able to remember, to learn how to remember and to stop making things look nicer and finding excuses all the time, which is typical of the nation, too. That leads nowhere. Instead, I recommend forgiveness. It is a much stronger, fairer thing. It is no less than the fight of sincerity and love. And this fight, of course, is to be taken metaphorically, as it is a constant change of real, living relations. It develops and breathes, as it were, as long as it is important to us. Not an exhibit in a museum.

[Azt gondolom, ha a szeretteink életét elkezdjük idealizálni, ha minden régi történet megszépül, és az eltávozott szeretteink szép lassan glóriát kapnak a fejükre, akkor az bizony a felejtés glóriája lesz. Ha tényleg szeretsz valakit, akkor a szereteted ad elég eröt, hogy el is tudd fogadni olyannak, amilyen, vagy amilyen volt. Ha képes vagy az empátiád segítségével felismerni a motivációit, a gyengéit, és megérteni a tévutakat az életében, azt is megtudod, a kudarcai miért kudarcok, és miért alakult úgy az élete, ahogy. Így tudsz kezdeni valamit a sorsával. Márpedig annak a sorsnak köze van a te sorsodhoz. Ezért nagy a felelösségünk abban, hogy tudjunk, tanuljunk emlékezni, és ne legyen bennünk az egyébként a nemzetre is jellemzö folytonos szépités, magamentegetés. Az nem jó semmire. Helyette a megbocsátást javaslom. Sokkal erősebb, igazabb dolog. Ez nem más, mint az öszinteség és a szeretet harca. És a harc természetesen idézőjeles, hiszen ez a valódi élö viszonyok folyamatos változása. Mindaddig alakul, lélegzik, míg fontos számunkra. Nem valami vitrinbe tett dolog] (Grecsó 2019: 14).

It is such sincere, uncompromising and courageous attitude which has enabled and will enable literature to reflect, contemplate and shape Hungarian identity. 
Kenyeres, János. "Manifestations of Hungarian Identity in Literature.” Hungarian Cultural Studies. e-Journal of the American Hungarian Educators Association, Volume 12 (2019) DOI: 10.5195/ahea.2019.347

\section{Works Cited}

Babits, Mihály. 1939. “A magyar jellemröl” ['On the Hungarian Character']. Mi a magyar? ['What is the Hungarian?']. Ed. Gyula Szekfü. Budapest: Magyar Szemle Társaság: 37-86.

Babits, Mihály. 2018. "On the Hungarian Character.” Translated by Richard Robinson. What is the Hungarian?: Masters of Hungarian Essay on Identity. Ed. Béla Márkus. Budapest: MMA Kiadó: 81-138.

Dani, Erzsébet. 2015. "The Intercultural Communicative Habits of Noncolonizable Székely Identity: Áron Tamási's Ábel Trilogy.” International Journal of Humanities and Social Science 5.4 (1) April: 143-154. http://www.ijhssnet.com/journals/Vol_5_No_4_1_April_2015/16.pdf

Dobozy, Tamás. 2005. Last Notes and Other Stories. Toronto: Harper Perennial.

Esterházy, Péter. 2005. "Mi a mi?" ['What is Us']. Mi a Magyar? ['What is the Hungarian?']. Eds. Ignác Romsics and Mihály Szegedy-Maszák. Budapest: Habsburg Történeti Intézet: 5766.

Fábri, Ferenc. 2009. “Mélymagyar.” Élet és Irodalom LIII.21. 22 May. https://www.es.hu/cikk/2009-05-25/fabri-ferenc/melymagyar.html

Grecsó, Krisztián. 2019. "Szépítés helyett a megbocsátást javaslom" ['I suggest Forgiveness Instead of Making Things Look Nicer']. A sziv 105/3 March: 12-16.

Grendel, Lajos. 2005. "Magyar traumák - magyar téveszmék" [Hungarian Traumas - Hungarian Delusions']. Mi a Magyar? ['What is the Hungarian?']. Eds. Ignác Romsics and Mihály Szegedy-Maszák. Budapest: Habsburg Történeti Intézet: 75-91.

Hellenbart, Gyula. 2009. "Mélymagyar.” Élet és Irodalom. LIII.20 15 May. https://www.es.hu/cikk/2009-05-18/hellenbart-gyula/melymagyar-.html

Illyés, Gyula. 2003. Puszták népe ['People of the Puszta']. Budapest: Osiris Kiadó.

Kenyeres, János. 2011a. "1956 in Cultural Memory: The Testimony of Literature." Confrontations and Interactions: Essays on Cultural Memory. Eds. Bálint Gárdos et al. L'Harmattan: Budapest. 59-67.

Kenyeres, János. 2011b. “'From Inert Landscapes’ to 'Walls Scrubbed Clean': Identity in Contemporary Canadian Short Fiction.” Ritka művészet / Rare Device. Eds. Veronika Ruttkay et al. Budapest: Eötvös Loránd Tudományegyetem. 352-359.

Kenyeres, Zoltán. 2004. Korok, pályák, müvek - Válogatott tanulmányok ['Periods, Careers, Works: Selected Studies']. Budapest: Akadémiai Kiadó.

Keresztury, Dezső, ed. 1955. Arany János összes költeményei ['The Complete Poems of János Arany']. Vol. I. Budapest: Szépirodalmi Könyvkiadó.

Kertész, Imre. 1993. Sorstalanság ['Fatelesness’]. Budapest: Századvég Kiadó. 
Kenyeres, János. "Manifestations of Hungarian Identity in Literature.” Hungarian Cultural Studies. e-Journal of the American Hungarian Educators Association, Volume 12 (2019) DOI: 10.5195/ahea.2019.347

Makkai, Adam, ed. 2000. In Quest of the "Miracle Stag”: The Poetry of Hungary. Chicago: Atlantis-Centaur.

McLuhan, Marshall. 1964. Understanding Media: The Extensions of Man. New York: New American Library.

Mohanty, Satya P. 1997. Literary Theory and the Claims of History: Postmodernism, Objectivity, Multicultural Politics. Ithaca: Cornell UP.

Móricz, Zsigmond. 1930. “Szabolcska Mihály.” Nyugat Vol. II: 717.

Moya, Paula M.L. 2000. "Introduction: Reclaiming Identity." Reclaiming Identity: Realist Theory and the Predicament of Postmodernism. Eds. Paula M.L. Moya and Michael R. Hames-García. Berkeley, Calif.: University of California Press: 1-26.

Németh, László. 1989. “Kisebbségben” ['In Minority’]. Sorskérdések. Budapest: Szépirodalmi Könyvkiadó: 408-482.

Németh, László. 2014. "Fantomok ellen” [“Against Fantoms'] (1942). A minőség forradama Kisebbségben - Politikai és irodalmi tanulmányok, beszédek, vitairatok ['The Revolt of Quality - In Minority: Political and Literary Studies, Speeches, Pamphlets']. Budapest: Petőfi Irodalmi Múzeum. https://opac.dia.hu/record//record/display/manifestation/PIMDIA10998/faa2d998-ec47-446c-a48e2d2f95c9c1c5/solr/0/24/2/24/authorOrder/ASC

Nyáry, Krisztián. 2019. "A Himmusz kalandos története" ['The Adventurous Story of the Anthem']. Válasz Online 01.22. https://www.valaszonline.hu/2019/01/22/nyary-krisztian-ahimnusz-kalandos-tortenete/

Tamási, Áron. 1934. Ábel Amerikában [“Ábel in America’]. Budapest: Magyar Elektronikus Könyvtár. http://mek.oszk.hu/01000/01084/01084.pdf

Trencsényi, Balázs, et al. 2018. A History of Modern Political Thought in East Central Europe: Volume II: Negotiating Modernity in the "Short Twentieth Century" and Beyond, Part I: 1918-1968. Oxford: Oxford UP. 